\title{
Change and contract management modules of intelligent-rogram management information systems (i- PgMIS) for urban renewal projects
}

\author{
Yong Woon Cha, Run Zhi Jin *, Myoung Jin Son, and Chang Taek Hyun \\ Department of Architectural Engineering, University of Seoul, Seoul, Korea \\ *Corresponding author (runzhijin79@hanmail.net)
}

\begin{abstract}
Purpose In recent times, urban renewal (UR) projects actively try to improve residential environments and recover functions of an urban infrastructure. These projects move forward simultaneously as multiple projects, rather than as one single project. To cope with this, program management techniques and a comprehensive management system which is based on these techniques are required. For this purpose the research team has developed an intelligent program management information system, i- PgMIS, that can efficiently manage and support urban renewal projects during the entire life cycle. Method The system provides cost management, duration management, risk management, performance management, green VE/LCC (Value Engineering/Life Cycle Cost), change management, contract management, an emanual, and conflict management for UR-projects. This paper details the research that focuses on the change management and the contract management modules. Motawa et al. proposed a change management system for construction projects at project level by using the dynamic planning system based on fuzzy logic, and Zhao et al. proposed a prediction change management system for each activity at the construction phase by using the dependency structure matrix (DSM). In this study, change factors that commonly occur in URprojects were first deducted by using the analytic network process (ANP), and the possibility of the change was estimated by using a Likert-scale. There is no specific method in the contract management module. The module focuses on how to manage contractors' information, the collection of the contract documents, execution of the costs referred to in the contract documents, and so forth. Results \& Discussion Since many changes take place and multiple contracts are signed during the progress of a mixed-use development project such as urban renewal projects, efficient management is essential to handle these projects successfully. It is expected that the project manager is able to efficiently manage contract duties and respond to a number of changes such as cost overrun and schedule delay during the project through the change management and contract management modules, as developed in this paper.
\end{abstract}

Keywords: change management, contract management, i-PgMIS, urban renewal

\section{INTRODUCTION}

Urban renewal(UR) projects have been actively implemented worldwide in recent years to promote improvement of the residential environment and functional recovery of underdeveloped cities. Since UR projects require large-scale project cost, longterm project duration and simultaneous progress for multiple projects ${ }^{1}$, there have been limitations in the management of UR projects using existing project management approaches. To this end, the world's leading construction companies have conducted many investment activities and researches to apply IT technologies in construction projects ${ }^{2}$, thereby developing the Project Management Information System (PMIS) with technologies providing a substantial level. In Korea, with the introduction of construction management, the need to standardize construction information has been raised. Construction PMIS has been expanded as one of the essential tools for the success of projects ${ }^{3}$. However, since PMIS is mainly used in the construction phase for a single project, its application to urban renewal projects is limited in terms of simultaneous implementation of multiple projects ${ }^{4}$.

In this regard, our research team developed the intelligent-Program Management Information System (i-PgMIS). i-PgMIS is a web-based system that integrates unit modules of cost/duration management, risk management, performance management, Green VE/LCC, change management, contract management, E-Manual, and conflict management. This study is focused on the development of change management and contract management modules among the various modules described above.

\section{LITERATURE REVIEW}

\section{Change \& Contract Management System}

In this study, the existing major researches on change management were first reviewed.

Oh $(2002)^{5}$ suggested a change management system for progress control, which considers progress delays caused by change order. Charoenngam et. al. 
$(2003)^{6}$ developed a management system for change order that supports integration, communication and documentation practices transpiring among a variety of subject participants. Motawa et.al. $(2007)^{7}$ developed a system to assess the impact and predict changes using fuzzy logic and Dynamic Planning and control Methodology (DPM). Zhen et.al. $(2010)^{8}$ developed a system to predict changes by establishing the standards by re-work of the construction phase based on the Dependency Structure Matrix (DSM), and analyzed the probability of change on the predicted changes by using the Monte Carlo Simulation(MCS).

Existing studies on change management mainly focused on prediction changes and evaluation the degree of impacts. Most of them were developed in the form of individual systems and there was no research presenting the supporting of the construction management by connection with other systems. The main contents of the previous studies on contract management include checklist development ${ }^{9}$ and management plans ${ }^{10,11}$, and some of the modules of Enterprise Resources Planning(ERP) conducted the contract management ${ }^{12}$.

Existing studies on contract management mainly dealt with the efficiency of management and claims prevention rather than system development. In addition, since EPR has been widely applied to finance and accounting for corporate management, it has its limitations when applied in construction project management.

The abovementioned studies are summarized in Table 1.

Table 1. Literature Review

\begin{tabular}{|c|c|c|}
\hline Category & Author & Subtance \\
\hline \multirow{4}{*}{$\begin{array}{l}\text { Change } \\
\text { Mgmt. }\end{array}$} & $\begin{array}{l}\text { Oh S. J. } \\
(2002)\end{array}$ & $\begin{array}{c}\text { Development of change } \\
\text { mgmt. system for schedule } \\
\text { mgmt. }\end{array}$ \\
\hline & $\begin{array}{c}\text { C. } \\
\text { Charoenngam } \\
\text { et. al. } \\
\text { (2003) }\end{array}$ & $\begin{array}{l}\text { Development of change } \\
\text { orders mgmt. system. }\end{array}$ \\
\hline & $\begin{array}{l}\text { Motawa et. al. } \\
\text { (2007) }\end{array}$ & $\begin{array}{l}\text { Development of change } \\
\text { prediction and change effect } \\
\text { evaluation system using the } \\
\text { DPM and the Fuzzy Logic }\end{array}$ \\
\hline & $\begin{array}{l}\text { Zhen et.al. } \\
\text { (2010) }\end{array}$ & $\begin{array}{l}\text { Development of change } \\
\text { mgmt. system using the } \\
\text { DSM for construction phase }\end{array}$ \\
\hline \multirow{3}{*}{$\begin{array}{l}\text { Contract } \\
\text { Mgmt. }\end{array}$} & $\begin{array}{l}\text { Lee S. H. } \\
(2000)\end{array}$ & $\begin{array}{l}\text { Proposed contract manage- } \\
\text { ment checklist. }\end{array}$ \\
\hline & $\begin{array}{l}\text { Lee et. al. } \\
\text { (2009) }\end{array}$ & $\begin{array}{l}\text { International construction } \\
\text { contracts with FIDIC sug- } \\
\text { gests to promote administra- } \\
\text { tive efficiency. }\end{array}$ \\
\hline & $\begin{array}{l}\text { Cha J. Y. } \\
(2001)\end{array}$ & $\begin{array}{l}\text { Contract management effi- } \\
\text { ciency through the claims } \\
\text { suggested the classification. }\end{array}$ \\
\hline
\end{tabular}

\section{Functions of i-PgMIS}

In this study, the analysis of the major technologies for program management was carried out for efficient management of UR Projects. The P(g)MIS such as e-Builder, PMweb, MOCA, and Proliance developed mainly been used to manage programs or projects in the US, was particularly analyzed. Fig. 1 shows a summary of the major functions included in the iPgMIS and systems mentioned earlier.

As identified in Fig. 1, asset management, facility management and energy management were not included in the functions of i-PgMIS. On the other hand, performance management, conflict management and green VE/LCC were included as additional functions. The functions included in i-PgMIS were finally determined in consideration of the expert's opinions and characteristics and budget of this research project.

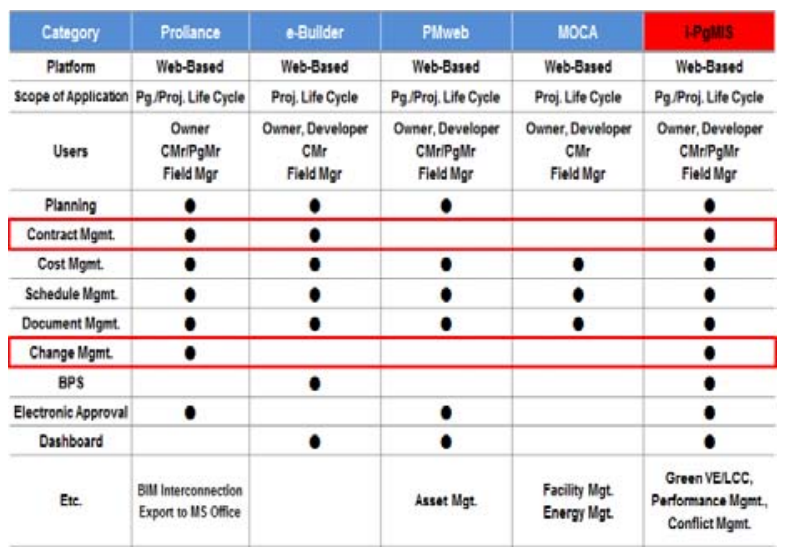

Fig.1. Comparative Table of Major $P(g)$ MIS \& i-PgMIS

\section{Development of Change Management Module}

\section{Evaluation Criteria for Change Factors}

Due to various change factors such as contracts, methods, regulations and business environment, large-scale programs such as UR Projects have a huge effect on the overall business. This impact of the change factors may leads to a project delay, cost overrun, and reducing feasibility.

Accordingly, in this study the evaluation criteria for the change factors affecting the business were deduced before the development of change management modules. First, expert interviews were conducted to deduce the evaluation criteria suitable for the UR projects based on the nine change factors presented in the Project Management Body of Knowledge (PMBoK), and the results were delivered through integration or addition/deletion by reflecting the similarities between factors as shown in Table 2. 'Risk management' was deleted since its' contents are applicable to all parts. 
Table 2. Evaluation Criteria from PMBoK

\begin{tabular}{|c|c|c|c|}
\hline No. & $\begin{array}{c}\text { Change Factors of } \\
\text { PMBoK }\end{array}$ & $\begin{array}{c}\text { Evaluation } \\
\text { Criteria }\end{array}$ & Notes \\
\hline$\overline{11}$ & IIntegration Mgmt. & \multirow{3}{*}{ Projects plan } & \multirow{3}{*}{ Integration } \\
\hline 2 & Scope Mgmt. & & \\
\hline 3 & Procure Mgmt. & & \\
\hline 4 & Time Mgmt. & $\begin{array}{l}\text { Projects Sched- } \\
\text { ule }\end{array}$ & Remain \\
\hline 5 & Cost Mgmt. & Projects Cost & Remain \\
\hline 6 & Quality Mgmt. & $\begin{array}{l}\text { Quality/ Safety } \\
\text { Environment/ }\end{array}$ & Add. \\
\hline 7 & $\begin{array}{c}\text { Human Resource } \\
\text { Mgmt. }\end{array}$ & \multirow{2}{*}{ Stakeholder } & \multirow{2}{*}{ Integration } \\
\hline 8 & $\begin{array}{c}\text { Communications } \\
\text { Mgmt. }\end{array}$ & & \\
\hline 9 & Risk Mgmt. & All parts & Delete \\
\hline
\end{tabular}

Since the range of specific changes are too wide for the five evaluation criteria, the detailed evaluation items of the five evaluation criteria were deduced through a questionnaire survey on 3 UR projects currently implemented in Korea, targeting 11 personnel in charge of UR projects. From its result, 64 detailed evaluation criteria were additionally deduced. Among them, the same and similar items were integrated to finalize a set of 22 evaluation criteria. Table 3 shows the summarized results.

\section{Development of Change Management Process}

In case of changes in specific activities within the business process, it is very important to determine how much impact the changes has on the overall business and other activities and what measures should be taken.

To support this, a process for change management was developed in this study. The change management process is divided into four stages: Identification $\rightarrow$ Evaluation $\rightarrow$ Approval $\rightarrow$ Notice. The contents are schematized in Fig. 2.

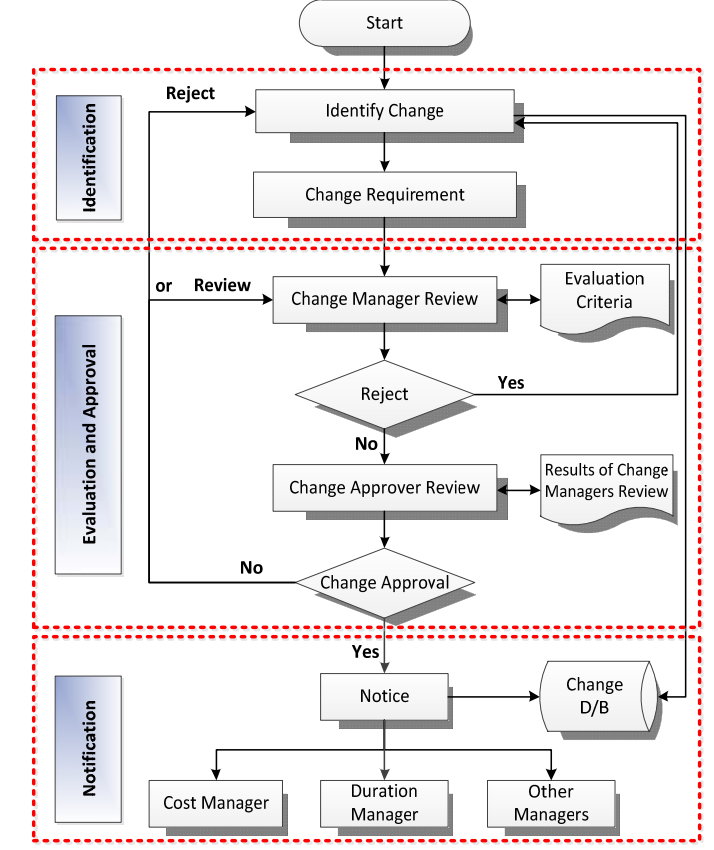

Fig. 2. Change Management Process
Table 3. Deduction of Evaluation Criteria for Change Factors

\begin{tabular}{|c|c|c|c|}
\hline No. & $\begin{array}{c}\text { Evaluation } \\
\text { Criteria }\end{array}$ & No. & Sub-criteria \\
\hline \multirow{5}{*}{1} & \multirow{5}{*}{$\begin{array}{l}\text { Projects } \\
\text { plan }\end{array}$} & 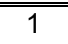 & Difficulty in financing \\
\hline & & 2 & $\begin{array}{l}\text { Concerned about } \\
\text { design error }\end{array}$ \\
\hline & & 3 & $\begin{array}{l}\text { Project cancelation } \\
\text { due to profitability }\end{array}$ \\
\hline & & 4 & $\begin{array}{l}\text { Issues regarding sur- } \\
\text { rounding infrastructure }\end{array}$ \\
\hline & & 5 & $\begin{array}{l}\text { Insufficient business plan- } \\
\text { ning due to equity problem }\end{array}$ \\
\hline \multirow{6}{*}{2} & \multirow{6}{*}{$\begin{array}{l}\text { Projects } \\
\text { Schedule }\end{array}$} & 6 & $\begin{array}{c}\text { Delay in } \\
\text { licensing procedure }\end{array}$ \\
\hline & & 7 & $\begin{array}{c}\text { Delay in } \\
\text { construction completion }\end{array}$ \\
\hline & & 8 & $\begin{array}{l}\text { Delay in existing } \\
\text { building disposition }\end{array}$ \\
\hline & & 9 & Delay in trial run \\
\hline & & 10 & Difficulty in material supply \\
\hline & & 11 & $\begin{array}{c}\text { Additional } \\
\text { construction work }\end{array}$ \\
\hline \multirow{4}{*}{3} & \multirow{4}{*}{$\begin{array}{l}\text { Projects } \\
\text { Cost }\end{array}$} & 12 & Poor construction work \\
\hline & & 13 & Interest increase \\
\hline & & 14 & Project delay \\
\hline & & 15 & $\begin{array}{c}\text { Additional } \\
\text { construction cost }\end{array}$ \\
\hline \multirow{4}{*}{4} & \multirow{4}{*}{$\begin{array}{c}\text { Quality/ } \\
\text { Environ- } \\
\text { ment/ } \\
\text { Safety }\end{array}$} & 16 & Safety accident \\
\hline & & 17 & deterioration in quality \\
\hline & & 18 & Noise problem \\
\hline & & 19 & Environmental issues \\
\hline \multirow{3}{*}{5} & \multirow{3}{*}{ Stakeholder } & 20 & $\begin{array}{c}\text { Delay in contract } \\
\text { performance }\end{array}$ \\
\hline & & 21 & Civil complain \\
\hline & & 22 & $\begin{array}{l}\text { Conflict between } \\
\text { participants }\end{array}$ \\
\hline
\end{tabular}

Identification

In the Identification stage, changes are perceived and requested. In this stage, a change requestor designates a reviewer and an approver, wherein the change reviewer can be a manager in charge of main categories of Table 3, and the change approver can be a general project manager or an owner. In this stage, the change requestor should attach relevant documents or papers to help the change reviewer or approver in the next processes.

\section{Evaluation and Approval}

These two stages contain a significant amount of information as the most important stage in the change management process. In particular, accurate assessment of changes can be conducted by making the change reviewer and approver independent of each other.

Once review requests on changes are received from the identification stage, change manager(s) conduct the assessment based on the evaluation criteria 
(sub-criteria of Table 3) using the 5-point Likert scale. When assessment is completed, the evaluation scores are calculated automatically, and then approval on changes is requested along with the evaluation results. However, the progress is return to the first stage if half of the reviewers reject the changes. Next, approval on changes is received, where the change approvers give a final approval after validation. However, they can reject the request for approval or ask the change reviewer to review the evaluation results if they are deemed inadequate. All the information generated in the earlier processes is stored in the change D/B.

\section{Notification}

The notification is the final stage in the change management process. As mentioned above, since the changes in specific activities affect other activities, managers in charge should recognize the approved changes and undertake follow-up measures. However, since the follow-up measures vary depending on the changes, it is difficult to present concrete countermeasures through this study. Accordingly, notification comes in the final stage of the change management process.

\section{User Interfaces(UIs) for Change Management Module}

As mentioned earlier, the change management module was developed into 4 steps and the main Uls are as follows:

1) "Change Requirement UI" - requests for review on the changes based on related information after perceiving changes

2) "Change Evaluation UI" - evaluates changes

3) "Change Approval UI" - approves the final evaluation results

4) "Change Result UI" - identifies the approved change results

\section{Change Requirement}

Initial changes are perceived offline, and when change is needed, the relevant information is collected. Based on the information, reviewers approve changes after the review process. The change requirement UI for receiving approval is shown in Fig.3.

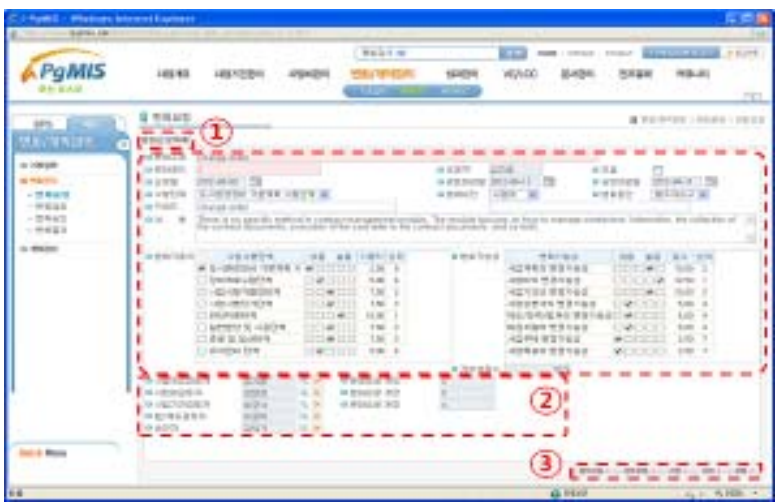

Fig. 3. Change Requirement

First, the information regarding changes such as change title, change code, request date, requestor, matter of urgency, change factors, keywords and the details of the requested change are registered (see

of Fig. 3). Next, a change requestor designates the reviewers and approver who can review and approve the requested changes (see of Fig. 3). In

of Fig. 3, additional files can be registered by clicking 'attachments', and change request is completed by clicking 'review request'.

\section{Change Evaluation}

The UI for change evaluation was developed based on evaluation criteria as shown in Fig. 4.

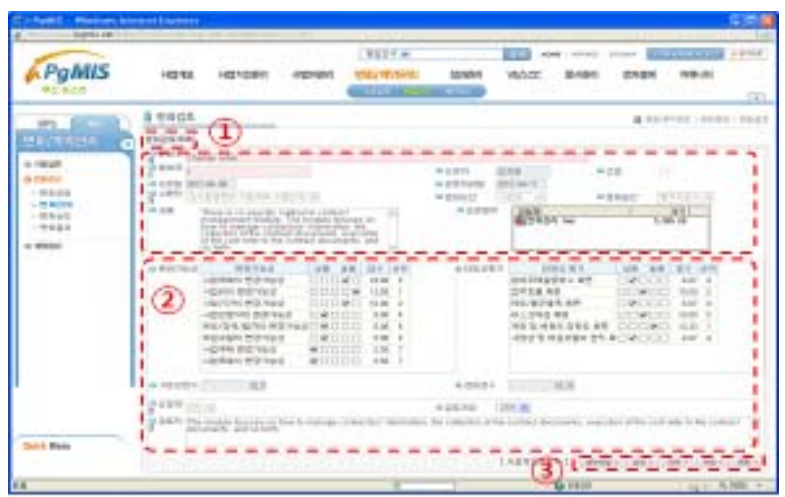

Fig. 4. Change Evaluation

In case of change review, the relevant information can be identified by reviewers specified in the Change Requirement. First, the basic information registered at the Change Requirement stage is presented in of Fig. 4. In of Fig. 4, evaluation is carried out based on the evaluation criteria deduced earlier by means of the 5-point Likert scale. After the evaluation is completed, approval is requested by clicking 'review completion' in of Fig. 4. If evaluation scores are low or there is missing information, the change request is rejected and the process is returned to the identification step. Even if the changes were rejected, the information regarding the changes is stored in Change D/B for change history management. 


\section{Change Approval}

In this stage, the final decision is made by identifying all the requested information after the completion of review. The $\mathrm{UI}$ is shown in Fig. 5.

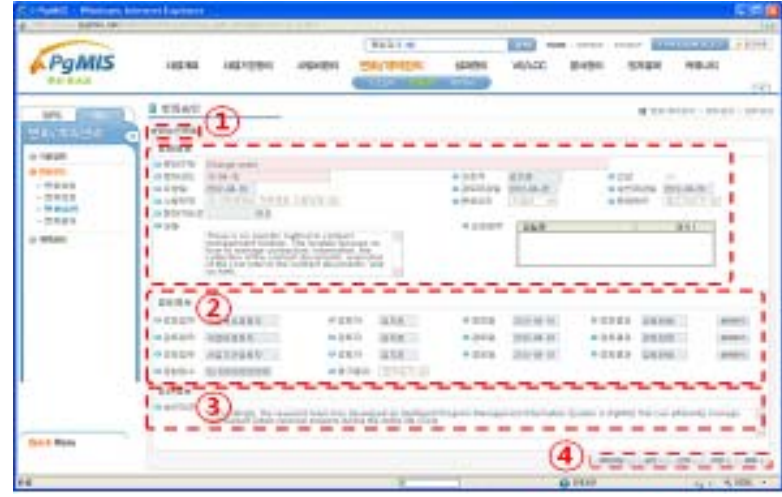

Fig.5. Change Approval

First, the change approver identify the information on the change requests (see of Fig. 5) registered in the change requirement stage and evaluation results by the change reviewers (see of Fig. 5) in the change review stage. More comments by reviewers can be seen by clicking 'details information' in of Fig. 5.

Approvers create a written approval (see of Fig. 5) by referring to the above contents, and subsequently give a final approval by clicking 'change approval' in

of Fig. 5 after completing the review. A 'review' can be requested to the change reviewers or the "reject" can be accepted if the contents are insufficient, it's depending on the results of the review. All the related information is stored in change $D / B$.

\section{Change Result}

In change Result UI, the approved changes can be identified on a list. Fig. 6 shows the details of the screen.

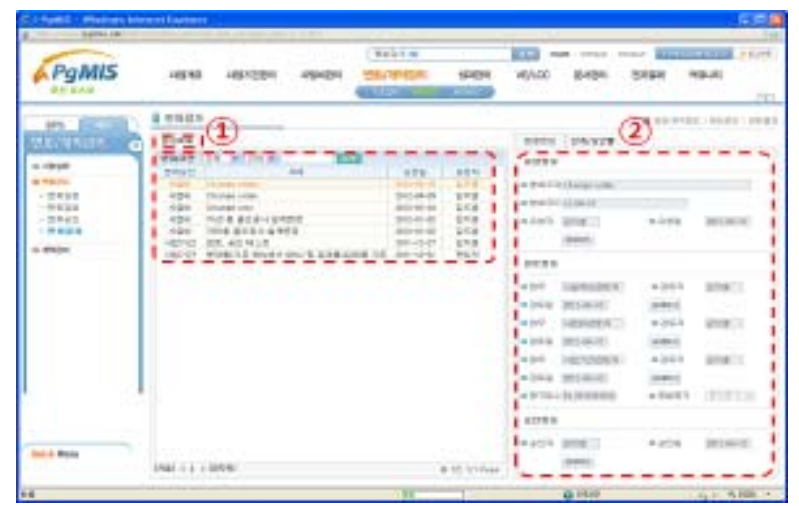

Fig. 6. Change Result

In of Fig. 6, each approved change can be searched through keywords, title, and requestors, and the detailed information regarding the changes can be identified in of Fig. 6 .

The notification was suggested in Fig. 2. The approved changes with a final approval are notified to each manager (Cost, Duration Managers, and etc.), who revises information on the approved changes after receiving the notice.

\section{Development of Contract Management Mod- ULE}

Deduction of Contract Management factors

In the process of implementing large-scale programs such as urban renewal projects, many participants perform tasks by entering into agreements. Details included in the contract documents can vary in accordance with type of the contract, but items such as contract amount, contract date and contracting parties are included in all contract documents.

In this study, to deduce required items included in contract management, the PMIS for management of a single project was analyzed, and based on the analyzed results, interviews with professionals in charge of the contract business were carried out. The results are summarized in Table 4.

Table 4.General Information for Contract Management

\begin{tabular}{cc}
\hline Category & General information \\
\hline \hline $\begin{array}{c}\text { Essential } \\
\text { information }\end{array}$ & $\begin{array}{c}\text { Contract name, type, method, date, } \\
\text { start day, end day and so on }\end{array}$ \\
\hline $\begin{array}{c}\text { Detail } \\
\text { information }\end{array}$ & Depending on the type of contracts. \\
\hline $\begin{array}{c}\text { Continuous } \\
\text { action. }\end{array}$ & $\begin{array}{c}\text { Mgmt. of contract history, } \\
\text { Mgmt. of execution history. }\end{array}$ \\
\hline Etc. & $\begin{array}{c}\text { Contract type grouping, } \\
\text { Contract information document. }\end{array}$ \\
\hline
\end{tabular}

\section{Development of Contract Management Process}

As a contract regarding the contractor cost can be changed due to change orders, a contract can be changed depending on the project's characteristics during the construction process. In this study, a process for contract management was developed based on the contract information deduced earlier, which is schematized in Fig. 7.

The contract management process of Fig. 7 is explained as follows: first, if a contract for the project is conducted, required items (refer to Table 5) are entered into the system, thereby registering the contract information. If the business is conducted in accordance with the terms of the contract, progress payment is executed according to the contract documents, and the contract is terminated. However, in case contract changes are requested, relevant information is required, and the contract information is reregistered when the executed progress payment is continuously accumulated. It must be managed until the total contract price is executed. 


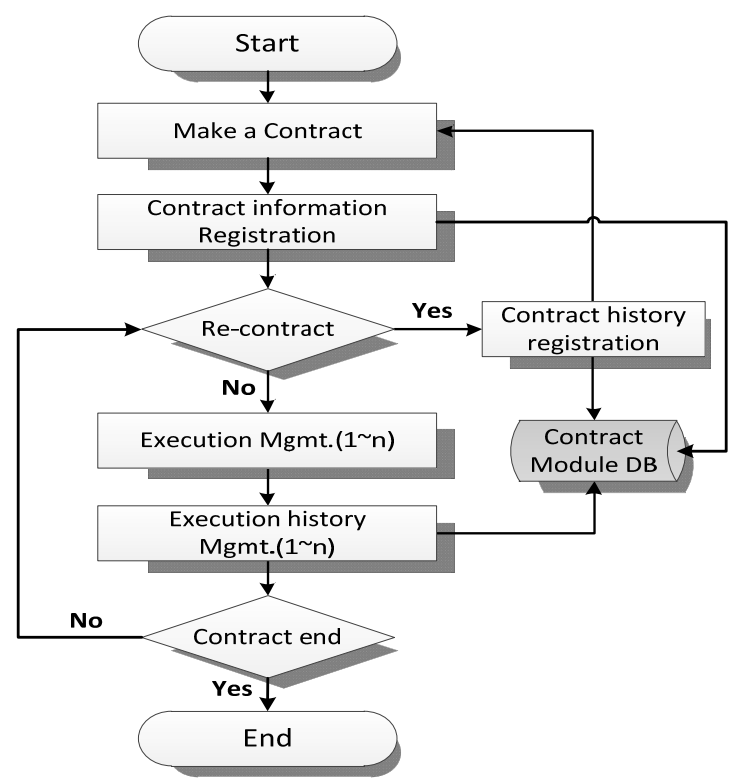

Fig.7. Contract Management Process

\section{Uls of Contract Management Module}

In this study, a contract management module was developed based on the contents deduced earlier. The Uls included in the contract management module are divided into the following categories: "contract information registration UI," which registers required contract information in case of making a contract; "contract history management UI" and "execution history management UI" for continuous management of the contract contents in the process of implanting the projects. In addition, "contract status UI" which identifies lists of the entire contracts; and "contractor management UI" which manages the detailed information of contractors are also included in the contract management module. Among the various Uls mentioned above, the "registration of contract information", "management of contract history" and "management of established history" are dealt with in this study.

\section{Registration of Contract Information}

Once a contract is made, the contract information is entered into the system for contract management. In this study, to manage the required information related to the contract summarized in Table 5, a UI was developed as shown in Fig. 8.

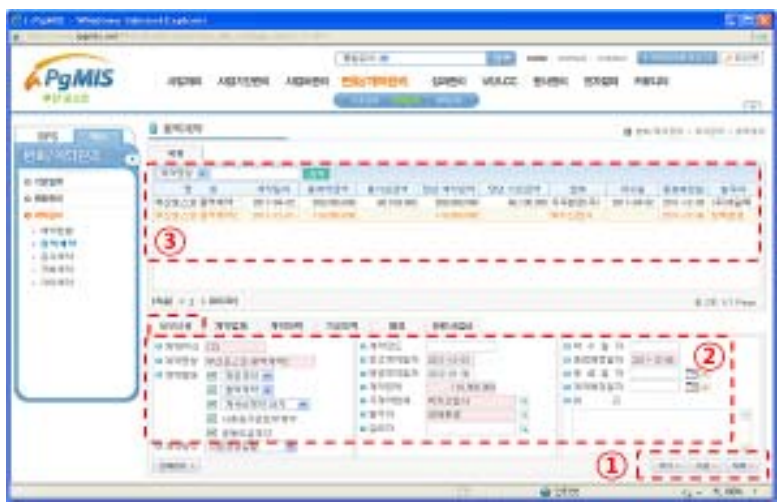

Fig. 8. Registration of Contract Information

First, click on 'Add' button (see of Fig. 8), the screen for entering the details (refer to Table 5) of the new contract is provided in of Fig. After entering the contract information, the contract manager stores the inputted details by clicking 'Store' button (see of Fig. 8), then the contract is added into the contract lists of of Fig. 8.

Whenever new contracts are made, the abovementioned process is repeated, and all contracts signed are recorded in the contract list of in Fig. 8 upon project completion.

\section{Management of Contract History}

Due to project specifications and circumstances, contract changes can be made at a certain point, which will require changes in the contract amount and date of progress payment. To deal with these changes, a function of contract history management was constructed in this study. Fig. 9 shows the $\mathrm{UI}$ for management of contract history.

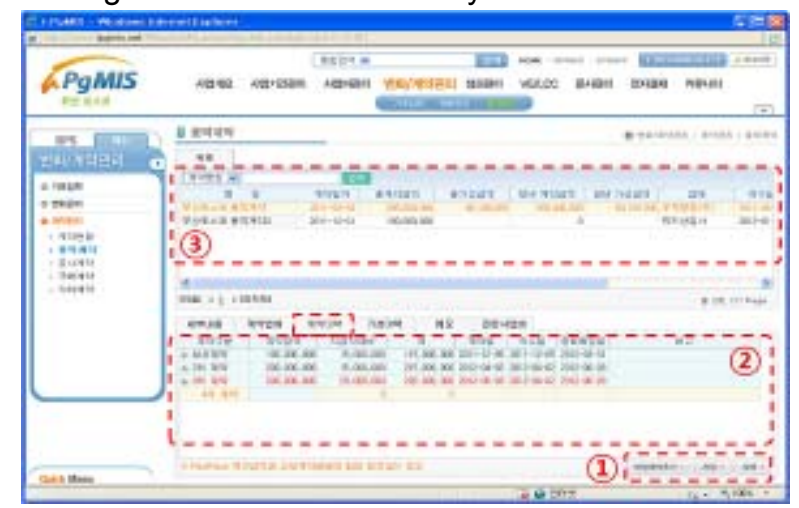

Fig. 9. Mgmt. of Contract History

First, one of the contracts for which contract changes are made is selected in contract list of in Fig. 9(the same as of Fig. 8). Next, information on the changed contents of the contract is entered in of Fig. 9 by clicking the 'Add changed contract' button of in Fig. 9, and then it is stored by clicking the 'Store' button of in Fig. 9. The changed information on the contract history is managed through linkage with information in Fig. 8. 


\section{Management of Execution History}

In general if it is a long-term project, the total contract cost is paid based on the order of payment division. In the case of construction work, progress payment is executed according to the earned value, and for design for CM contracts, the total cost is paid by monthly or quarterly installments. In this study, execution history management UI was developed for the management of the amount paid as time progresses, and is shown in Fig. 10.

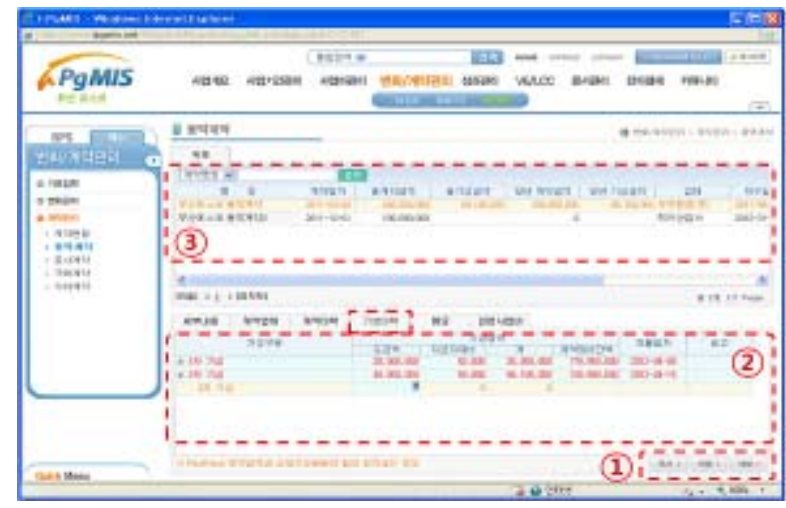

Fig. 10. Mgmt. of Execution History

First, one of the contracts is selected from the contract list of in Fig. 10 (the same as of Fig. 9). Next, the amount of execution and execution date of corresponding orders is entered in of Fig. 10 by clicking the 'Add' button of in Fig. 10. The execution results are then stored by clicking the 'Store' button of in Fig. 10.

Through the above process, the execution results of all contracts are registered for continuous management.

\section{CONCLUSION}

To promote improvement of the residential environment and functional recovery of underdeveloped cities, urban renewal projects have been actively implemented worldwide in recent year. However, since UR projects require simultaneous progress of multiple projects, there have been limitations in the management of UR projects using existing business management approaches. Therefore, the program based technologies are required.

To support this, our research team developed the iPgMIS which integrates several unit modules such as cost/duration management, risk management, performance management, green VE/LCC, change management, contract management, E-Manual and conflict management. This study dealt mainly with the development process of change management and contract management modules.

To develop change management modules, the evaluation criteria of change factors were first deducted and the change management process was developed. And then, the Uls for change management were developed. Likewise, in the development of contract management modules, contract management factors were deduced first, followed by Uls for contract management developed based on the development of the contract management process.

It is expected that the change management modules developed in this study could support decisionmaking regarding changes through quantitative evaluation of the changes that occurred during project implementation. In addition, the contract managers are expected to comfortably and easily manage the history of progress payment and changes in the contract that occurred during project implementation using contract management module.

\section{ACKNOWLEDGEMENT}

This research was supported by a grant (07 Urban Renaissance B03) from High-Tech Urban Development Program funded by the Ministry of Land, Transport and Maritime Affairs of the Korean Government.

\section{References}

1. Kim, G.R., Yu, J.H., "Suggest a Work process of Change Management in a Urban Regeneration Project", Korea Institute of Construction Engineering and Management 2010 Annual Conference, Vol. 10(1), pp.245-246, 2010.

2. Lim, C.W., Yu, J.H., Kim, C.D., "The Improvement Method of Time Management Function in PMIS Using the Work Relationship Analysis Method", Korea Institute of Construction Engineering and Management 2009 Annual Conference, Vol. 9(1), pp.537$541,2009$.

3. Lee, S.K, Lee, H.L., Yu, J.H., "The Effect of PMIS Quality on Project Management Success", Journal of the Korea Institute of Building Construction, Vol. 10(6), pp.117-126, 2010

4. Hyun et al., "Development of the Program management System for Mega Project in Urban Regeneration", Korea Institute of Construction Engineering and Management 2008 Annual Conference, Vol. 8(1), pp.176-183, 2008

5. Oh, S.J., "A Study on the Integration of Schedule Control and Change Control System", Cheung-Ang University Master Thesis, 2002.

6. Charoenngam, C., Coquince, S.T., Hadikusumo, B.H.W., "Web-based application for managing change orders in construction projects", Construction Innovation: Information Process, Management., Vol. 3(3), pp.197-215, 2003

7. Motawa, I.A. , Anumba, C.J., Lee, S., Peña-Mora, F. "An integrated system for change management in construction", Automation in Construction, Vol. 16(3), pp.368-377, 2007

8. Zhen, Y.Z., Qian, L.L., Jian, Z., George. Z., "Prediction System for Change Management in Construction Project", Journal of Construction Engineering and Management, Vol. 136(6), pp.659-669, 2010. 
9. Lee, H.S., "A Study on the Improvement for the Contract Management through Establishing the Check List of Standard Contract Documents", YonSei University Master Thesis, 2000

10. Lee, S.H., and Lee, J.S., "A study of the FIDIC and Improvement Plan about International Construction Contract Management to promote efficiency", Korea Institute of Construction Engineering and Management 2009 Annual Conference, Vol. 9(1), pp.15-18, 2009.

11. Cha, J.Y., "A study on improvement of contract administration by analyzing claim cases", Yon-Sei University Master Thesis, 2001.

12. Williams, G.C., "Implementing SAP ERP Sales \& Distribution”, McGraw-Hill, Inc., 2008. 